\title{
Nutmeg - Origin, diversity, distribution and history
}

\author{
B Sasikumar* \\ Division of Crop Improvement \& Biotechnology \\ ICAR-Indian Institute of Spices Research, Kozhikode-673 012, Kerala. \\ *Email: Sasikumarsooranadu@gmail.com
}

Received 23 August 2021; Revised 28 September 2021; Accepted 04 October 2021

\begin{abstract}
Nutmeg (Myristica fragrans Houtt.) a small holder's crop, with 3500 years of antiquity originated in the Moluccas, Indonesia, is now grown in about 12 countries including some secondary centres of domestication. Centres of domestication overlap the centre of origin in nutmeg. Out of about 175 species in the genus, only five are economically important. Besides species diversity and cultivar diversity, ecosystem diversity is also a component of biodiversity of the genus. The genus is represented by six species including four endemic species and subspecies each in India. A comprehensive work on Indian Myristica is pertinent. The history of the spice is mired in bloody wars, piracies, privateers, clandestine collection trips, wanton felling of the heirloom trees besides inadvertent specimen identity, inaccurate chronology and a treaty of land swap. Though French and British colonial rulers took interest in popularising nutmeg in their colonies albeit for economic gains, the role of French was pivotal. The package of practices of nutmeg (Colonial Horticulture) in the new French colonies were a complex process of creolizing the expertise borrowed from the native people of the Moluccas with the horticultural knowledge of the colonists, traders, settlers, slaves and other local residents. Though nutmeg, a perennial tree of about 100 years of life span, has only about 300 years of domestication history in the country, the cultivar diversity is amazing as exemplified by the high frequency of farmer's varieties. The nutmeg population of the country also exhibits good phenotypic plasticity as demonstrated by leaky dioecy. While the transnational spread of nutmeg is a legacy of colonial rulers, the settlers mainly Christians, are credited with the intrastate spread of nutmeg in Kerala, the major area of production in India. History of nutmeg is still in an emerging phase and there are gaps in our understanding.
\end{abstract}

Keywords: cultivar diversity, colonial rulers, domestication, ecosystem diversity, Myristica fragrans, taxonomic cleaning, treaty of Breda

\footnotetext{
${ }^{*}$ Current address: SEKT D6, Varada, Kurup's Lane, PO Sasthamangalam, Thiruvananthapuram-10, Kerala.
} 


\section{Introduction}

Nutmeg (Myristica fragrans Houtt.) popular for the twin spice it produces-nutmeg seed (kernel) and mace (aril covering the seed) - is an important spice found in the kitchens and bakeries across the world as well in the traditional pharmacopoeia. Considered to be originated in the Moluccas (Spice Islands) in Indonesia, the tree is now an important small holder's plantation crop in many countries. Unlike in many other crop plants, the centres of domestication encompasse the centre of origin in nutmeg. Including few secondary centres of domestication, the important nutmeg producing countries at present are Indonesia, India, Grenada, Sri Lanka, Malaysia, Mauritius, Zanzibar, Seychelles, Reunion Islands, Guatemala and Solomon Islands with Indonesia (34, 602 MT), India (15076 MT), Sri Lanka (5000 MT) and pre-hurricane Grenada ( 2000MT) leading in production (IFEAT 2021).

The history of the transnational spread of nutmeg is beset with its own share of rivalry, clandestine voyages, sea piracy, biopiracy and cash transfers besides lack of cogency on the chronology (Americas) and mistaken identity of the target specimen (Monodora myristica Dun known as 'Tobago nutmeg' or 'Jamaica nutmeg' and Pichurim nut Nectandra pichurim (Kunth Mez) instead of true nutmeg) (Zumbroich 2005).

\section{Origin and distribution of Myristica spp.}

The nutmegs, Myristica, are a genus of evergreen trees occurring in Africa, Asia, Pacific islands, and the Americas. New Guinea is considered as the centre of origin and distribution of Myristica genus (Ravindran 2017).

\section{Diversity}

Species diversity, ecosystem diversity and cultivar diversity are the components of Myristica diversity.

\section{a. Species diversity}

Species diversity in India is represented by five species viz., M. andamanica Hook. f. (1886 : 103), M. beddomei King (1891: 291), M. fragrans Houttuyn (1774: 333), M. magnifica Beddome (1869: 268) and M. malabarica Lamarck (1791: 162) (Fig.1) besides the recently reported Myristica trobogarii Govind \& M. Dan, though there are $\mathrm{ca} 175$ species worldwide (Govind et al. 2020; Mabberley 2018). Three new subspecies of $M$. beddomei King namely M. beddomei subsp. beddomei King, M. beddomei subsp. sphaerocarpa W.J.de Wilde and M. beddomei subsp. ustulata W.J.de Wilde are also described from India (Banik et al. 2017) in addition to the subspecies, M. fatua var. magnifica.

However, other species such as Myristica elliptica Wall. ex Hook. f. et Thoms, M. amygdalina Wall., Myristica glaucescens Hook. f. Thoms, Myristica prainii King, Myristica dactyloides Gaertn etc too are reported to occur in India (Bohra et al. 2019; Krishnamoorthyetal.2007).Someof theseentities could be synonyms such as $M$. amygdalina syn. Horsefieldia amygdalina; Myristica prainii King syn. Endocomia macrocoma subsp. prainii King; Myristica dactyloides Gaertn syn. M. malabarica etc. This confusion warrants a more systematic taxonomic study of the genus especially as no comprehensive work on Myristicaceae R. Br., nom. cons. in India has been done since Sir J.D. Hooker's the Flora of British India (1817-1911) and the family was treated with confusion in several regional floras, which were devoid of updated nomenclature and citation of type specimens (Banik et al. 2017).

Out of the six species reported from India, $M$. beddomei, M. magnifica, M. malabarica besides Myristica trobogarii and the subspecies $M$. fatua var. magnifica, M. beddomei subsp. beddomei, $M$. beddomei subsp. sphaerocarpa and M. beddomei subsp. ustulata are endemic to the Western Ghats.

Apart from the nutmeg of commerce Myristica fragrans Houtt., Myristica malabarica (Bombay 

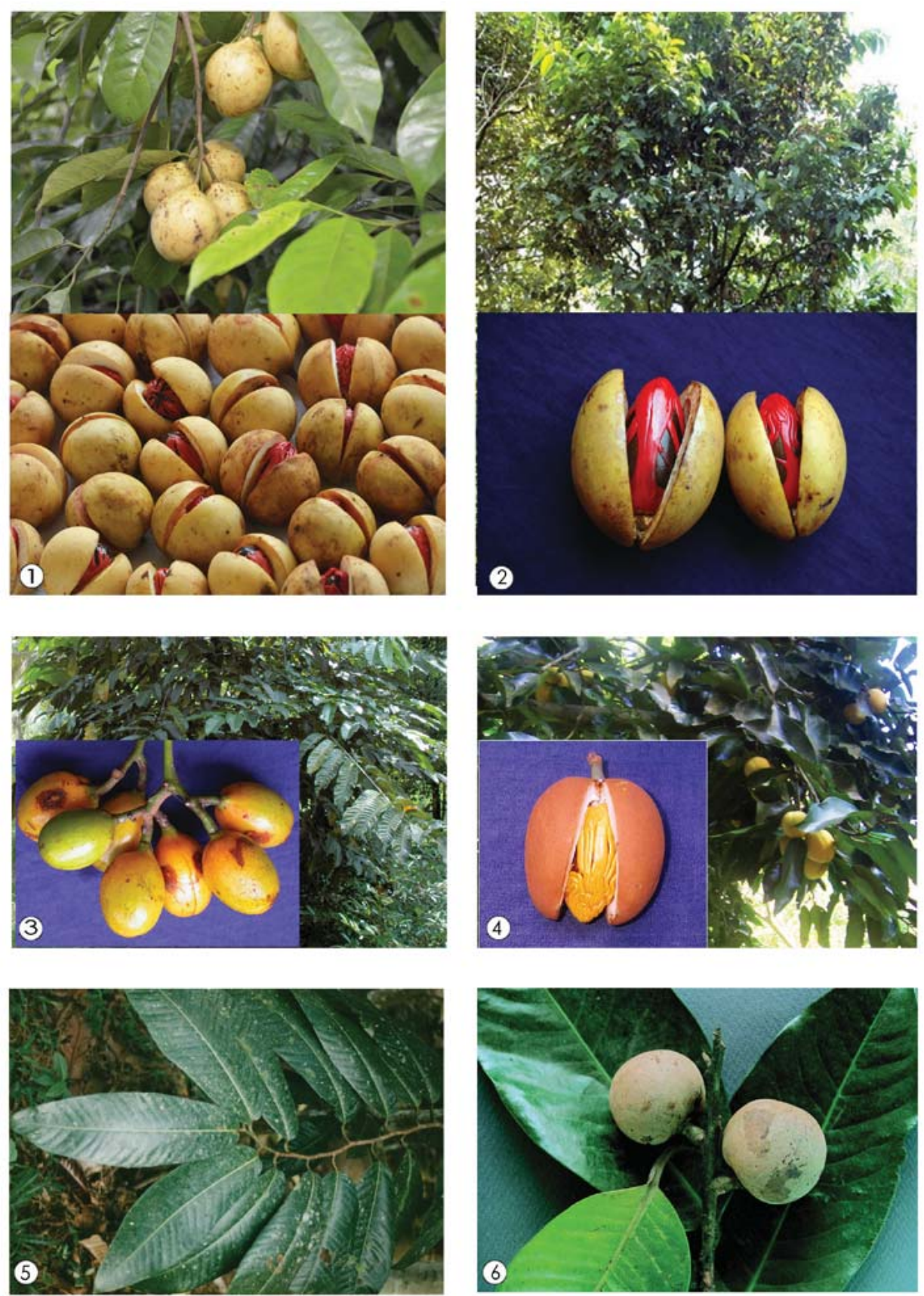

Fig. 1 Species diversity in Myristica:

1. Myristica fragrans, 2. Myristica andamanica, 3. M. prainii, 4. M. malabarica,

5. M. magnifica var. fatua, 6. M. beddomei

mace), M. andamanica Hook. f, M. beddomei King are used in medicine and/or dye industry (Arunachalam \& Subhashini 2011; Manjunatha et al. 2011) and Fakfak nutmeg or Papua Nutmeg (Myristica argentea Warb.), largely used in soap and perfume industries besides as a substitute for the common nutmeg are the economically important species. Fakfak nutmeg or Papua Nutmeg, grown in wild or semi wild condition in Indonesia, is a main cash crop in Fakfak and Kaimana Regencies of the country (Wahyuni \& Bermawie 2020). In fact, the British anthropologist Roy Ellen is of the view that the original nutmeg merchandised 
was not the Bandanese nutmeg (Myristica fragrans), but the long Papua nutmeg (Myristica argentea Warb.) (https://www.the jakarta post. com/paper/2020/12/29/a-sustainable-pathwayfor-papuan-nutmeg.html).

DNA barcoding ( $r b c L$, matK, $p s b A$-trnH, ITS) based phylogenetic studies revealed $M$. fragrans is closely related to $M$. beddomei, $M$. amygdalina, and $M$. andamanica whereas $M$. fatua is found to be distinct from M. malabarica. Gymnocranthera and Knema species were found to share sister relation with other Myristica spp. (Swetha et al. 2019). However, a mat K gene based phylogenetic analysis revealed close resemblance between $M$. fragrans and $M$. fatua (Nanlohy \& Semuel 2020). Based on $18 S$ rDNA study, Sheeja et al. (2014) also observed a close relationship between $M$. beddomei, $M$. andamanica and $M$. amygdalina besides between M. malabarica and $M$. fragrans. Myristica trobogarii, the recently reported species, shares morphological similarities with $M$. beddomei sub sp. beddomei, M. malabarica and $M$. magnifica, though it differs in many other attributes (Govind et al. 2020).

\section{b. Ecosystem diversity}

Though majority of Myristica species are of non swampy habitat, Myristica fatua Houtt. var. magnifica is exclusive to the Swamps with occasional occurrence of $M$. malabarica as well as $M$. beddomei subsp. sphaerocarpa, M. beddomei subsp. beddomei and M. beddomei subsp. ustulata (Saji et al. 2019; Banik et al. 2017). Gymnacranthera canarica is the other most common companion entity in the Swamps. Myristica swamps are a type of evergreen freshwater swamp forest harbouring diverse flora and fauna, unique to India. It is found in valleys of Kulathupuzha, Shendurney and forest ranges of Anchal in Kerala; Uttara Kannada, Dakshina Kannada and Shivamogga in Karnataka besides Goa and Bambarde of Sindhudurga Dist, Maharashtra in the Western Ghats, India (Sreedharan \& Indulkar 2018).

\section{c. Cultivar diversity}

Nutmeg, a predominantly dioecious tree, has a domestication history of less than 300 years in India by all probability. But the degree of varietal/cultivar diversity observed in a perennial crop like nutmeg, propagated mainly vegetatively, within in a span of about 300 years of domestication is very amazing (Haldankar et al. 2004; Vikram et al. 2016; Priyanka \& Mini Raj, 2016; Raj \& Nybe, 2019). Selection, either germplasm or true seedling progeny selection, has lead to a host of varieties including the Institution bred ones like IISR Vishwashree, Konkan Sugandha, Konkan Swad, and Konkan Shrimanthi; farmer participatory variety IISR Keralashree and about a dozen of farmer's varieties such as Kadukanmackel, Nova, Kallingal, Punnanthanam, Kochukudi, Kinattukara, Kallivayal, Ceylon, Ceylon-1, Naveswari, Pullan, Souwriyamakkal, Nirappel etc. Variants like yellow mace nutmeg and seed sterile mutant (Fig. 2) are also located and propagated from the primary genepool of the crop (Sasikumar et al. 2017; Saji et al. 2019). Recently, evolution of nutmeg towards monoecy (leaky dioecy) is also reported (Rema et al. 2014; Aarthi et al. 2018; Sasikumar \& Aarthi 2016). Morphological diversity of nutmeg mother trees and true seedling progenies is recorded from Indonesia too (Hetharie et al. 2015).

\section{History}

Archaeological excavations carried out during 2007 and 2009 at Pulau Ay, Banda islands in Moluccas (Spice Islands), a speck of island in the Banda atoll, indicate 3500 years of antiquity for nutmeg (Lape et al. 2018). Either due to the intrinsic quality of the produce or shrewd market maneuvering, the Spice Islands were frequented by Chinese, Malay, Javanese, and Arabo-Persian middlemen traders as early as $15^{\text {th }}$ century, whose accounts advanced the European dreams of the Spice Islands. Moluccas being the source of nutmeg remained arcane to the Western world, until an Arab trader by name Kazwini disclosed to the world 
the source of nutmeg - the elusive Moluccas, in CE 1300 (Wiess 2002). This disclosure was followed by aggressive voyages by various European explorers and traders to the nutmeg islands, in the next few centuries.

The Portuguese first succeeded to find the way to reach Moluccas after they conquered Goa (India) in 1510 and Malacca in 1511 under the commander of Afonso de Albuquerque and finally reached the Spice Islands of Banda and Penyu in two ships in the year 1512. Spices trade became the monopoly of the Portugese till the Dutch reached the Moluccas in the year 1599 (Pakpahan et al. 2019). Meanwhile the British merchants with the patronage of the Queen were also sponsoring voyages to the nutmeg island, since last decades of $16^{\text {th }}$ century (Milton 1999).

Fierce battles were waged between the Dutch and English as well as both with the native Bandanese to regain/retain the monopoly of nutmeg trade during 16 and 17th centuries. Horrific brutality, diabolic maneuvering, merciless slaying of the natives, mindless felling of nutmeg plantations, swapping of islets etc. were the signet of these trade wars (Aubery 2012). In 1616, the English had managed to wrench control of a Banda Island called Run from the Dutch, a tiny island less than 2 miles long and just more than half a mile wide. In fact, after many failed attempts and disasters, the English's first successful contact with the Spice Island is considered to be the Run (Milton 1999). It was here later the English claimed their first colony and established the English East India Company. However the English East India Company was able to defend Run against the Dutch only for four years - but they did not give up their claim though ousted and waited for the right opportunity to strike. The two jousted for superiority for long. In 1664, in retaliation, four English frigates were sent across the Atlantic Ocean to capture a Dutch holding called New Amsterdam (Manhattan was New Amsterdam in Dutch parlance) and the British established themselves in this island town and both defended each other's island. However, after 3 years, in 1677, the two countries came to an agreement known as the Treaty of Breda and swapped the islands. Thus, the Dutch gained control of Run and the English got New Amsterdam - a new colony they renamed Manhattan. That is the past story of today's affluent Manhattan (Topsfield \& Rompies 2017) (http://www.bbc.com/travel/ story/20171010-the-tiny-island-the-britishtraded-for-manhattan). Run, however lost its dominance and sheen as nutmeg cultivation gained momentum in other islands of Moluccas and even other parts of the world.

The French colonial powers, with the establishment of the French East India Company in 1664 (Wellington 2006), were also trying to have a finger in the nutmeg pie and were sponsoring overt and covert expeditions to Moluccas. Breaking the Dutch stranglehold, nutmeg was introduced to Isle de France (Mauritius) by Pierre Poivre, the French naturalist cum explorer who succeeded in procuring 32 numbers of nutmeg plants and transporting them to Isle de France (Mauritius) in 1753 and 1755 (Ly-Tio-Fane 1958; Drayton 2000) out of which only two nutmeg plants survived, and in 1769 Poivre embarked on another clandestine mission to the Moluccas which finally brought significant quantities of nutmeg plants and seeds to Isle de France in June 1770 (Warburg 1897a). One more successful collection trip to the Moluccas by Poivre from 1771 to 1772 brought more seeds to Isle de France (Sonnerat 1776) and Poivre sourced the help of interlocutors such as Jean Mathieu Simon Provost and others including, Chinese traders, Spanish and Portuguese allies in his mission. Pierre Poivre is also credited with introducing nutmeg to Pondicherry (Puducherry), a territory under French control in India, during one of his missions (CE 1753), as a transit station (Brixius 2015).

Evidence is also there about that one of the 

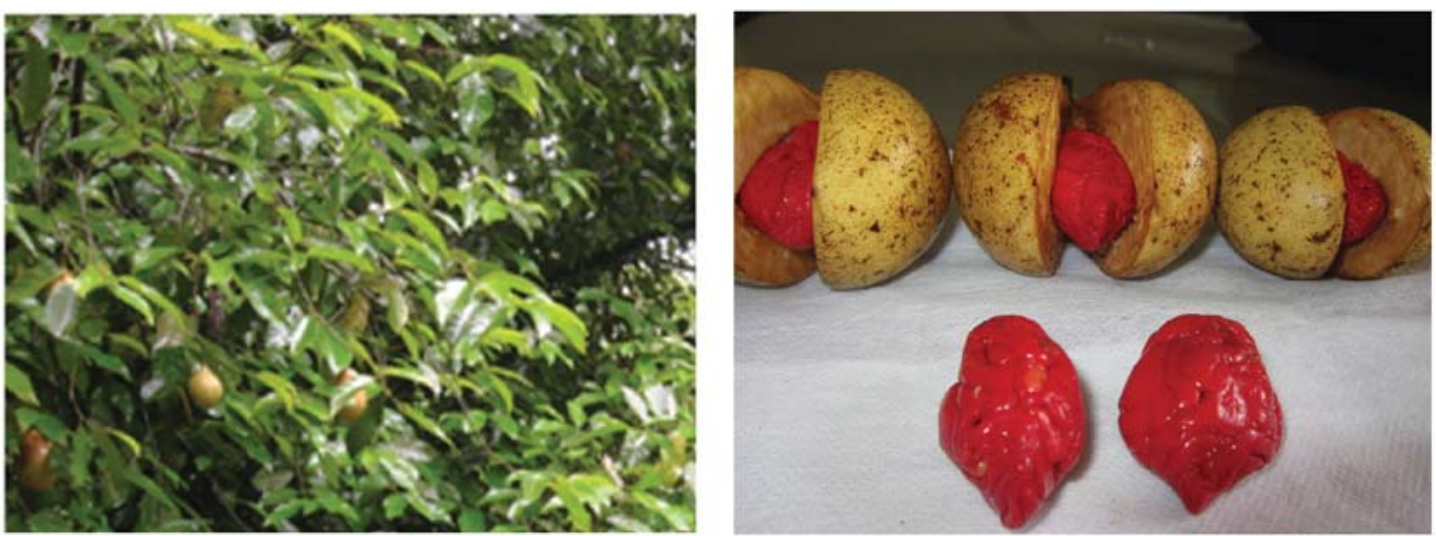

Seed sterile nutmeg
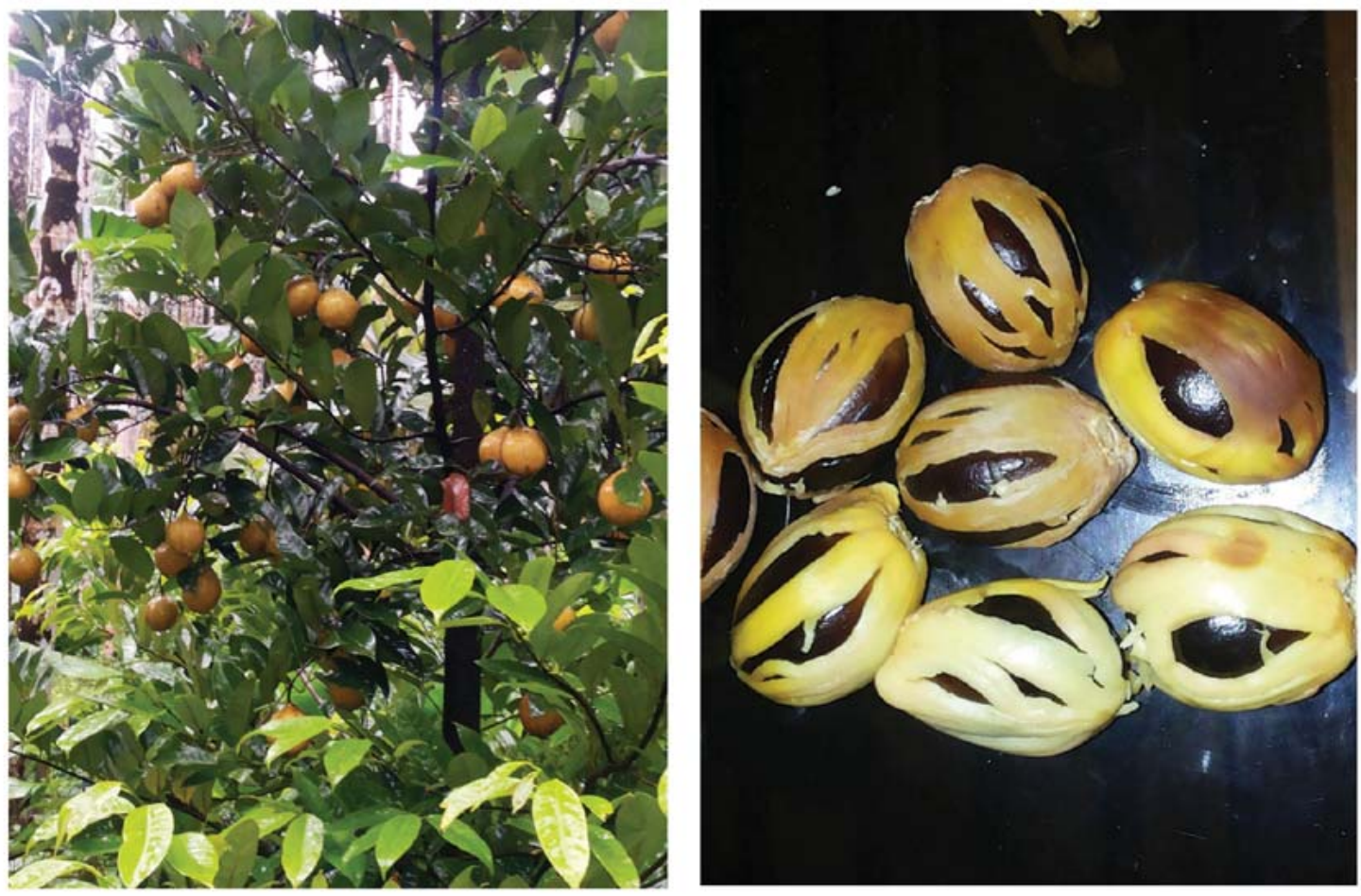

Yellow mace nutmeg

Fig. 2 Variability in nutmeg

(For interpretation of the references to colour in this figure, the reader is referred to the web version of this article.)

early 1770s French shipments of nutmeg plants felling into British pirates on its way to Isle de Cayenne (Zumbroich 2005).

Establishing nutmeg plants successfully in its new environments was a herculean task, as the commercial vision was not matching with the ground horticultural reality. Thus, nutmeg package of practices at Isle de France was a complex process of creolizing the expertise and accounts borrowed from the local people of the Spice Island with the horticultural knowledge of colonists, traders, settlers, gardeners, labourers and slaves living in Isle de Franc (Brixius 2018). A part from the agronomic issues, the sex problem and reproductive biology of nutmeg were a daunting task to the French masters at Isle de France. Though the native Moluccs were aware of 'Pala parampuan' (the female tree), 'Pala Lakki Parampuan' (female 
and long nutmeg) and 'Pala lakki-lakki' (wild male or long nutmeg), this ethnic botanical knowledge of the natives were either ignored or misinterpreted by the French masters mainly due to linguistic barriers (Brixius 2018). It was Mr. Cere, a later governor of Mauritius, who made the important discovery that nutmeg is unisexual, sometimes during 1778 (Wiess 2002). The French mastered the technique of nutmeg farming over a period by trial and error method. The role of the two indentured gardeners namely Charles Rama and Hilaire stands out in this regard.

The manual 'Instruction sur la manière de planter et de cultiver avec succès les plantes et les graines de Géroflier et de Muscadier' (Instruction on the manner of successfully planting and cultivating plants and seeds of clove and nutmeg) to local colonists by Poivre summarises the methods (Brixius 2018).

French colonial rulers were keen to introduce the crop to their other colonies. Thus on 3rd of February 1773, nutmeg was introduced to French Guyana from Isle de France which can therefore be considered the date of the introduction of Myristica fragrans to the Americas (Warburg 1897 a; Ly-Tio-Fane 1958), rather than the report of the French Botanist, Jean Baptiste D'Arnault in which he claimed to have collected 'nutmeg' (Tobago nutmeg' or 'Jamaica nutmeg' and Pichurim nut as true nutmeg) and cinnamon in the Lesser Antilles or Venezuela in 1767 (Lindorf 2001 \& 2002). The earliest preserved herbarium of Myristica fragrans from America (now in the British Museum herbarium) from a five year old tree of French Guyana too attests this record. A Prussian born naturalist Julius von Rohr prepared this herbarium specimen in 1784 (Warburg 1897 a \& b; Hopkins 1998).

Nutmeg was introduced to Seychelles, Reunion Islands and Zanzibar from the Mauritius stock during the later decades of 18 or early $19^{\text {th }}$ century (Weiss 2002).
About a devastating disease that wiped out the entire nutmeg plantations in Singapore during 1862 is also there in the annals of nutmeg history (Jaffrey 1860).

The British East India Company gradually gained control over nutmeg trade in the Moluccas and popularised nutmeg cultivation in their other colonies across the world. Thus by $18-19^{\text {th }}$ centuries nutmeg reached many countries like India, Mauritius, French Guyana, Grenada, Sri Lanka etc.- courtesy French and British colonial rulers and French explorers.

Nutmeg was first planted in Grenada on the Belvedere Estate (in St. John's Parish) by Hon. Frank Gurney in 1843, from seeds obtained from a called in merchant ship enroute to England from the East Indies. The first commercial plantation started in 1850 and by 1865 Grenada emerged as a major nutmeg producer and exporter (Singh et al. 2003). However, the devastating hurricane Ivan in 2004 caused widespread damage to the nutmeg plantations of Grenada and the island nation is now slowly recuperating from the destruction, with production touching 472.6 MT in 2020 (www.now grenada.com/2021/02/ nutmeg-farmers-told-opportunities-despite-covid19-challenge).

The spice has a colonial legacy in India. Though it is widely believed that nutmeg was introduced to India by the British East India Company during the $18^{\text {th }}$ century, it may be the French colonial policy to popularise spice plants in their own territories such as the transit shipment by Poivre mentioned earlier, paved the way for nutmeg reaching India. It is also mentioned that in 1750 a price of twenty thousand pieces of silver was offered to the person who would bring twenty-five nutmeg plants to the southern Indian port town of Pondicherry (Puducherry), a French colony (Zumbroich 2005). Thus, the British colonial legacy of nutmeg in India is doubtful. However it is unclear whether the discovery of the nutmeg's sexuality by the Mauritius Governor in 1778 has reached other French colonies in 
Indian ocean and if not how a dioecious plant like nutmeg would have survived remain a mystery but for any intersex trees.

The observation of Pickersgill (2005) that nutmeg spread to India during $6^{\text {th }}$ century $C E$, then further west to Constantinople through Arab traders, by all probability may be referring to nutmeg as an item of kitchen spice rather than a botanical entity. In the $17^{\text {th }}$ century work Hortus Botanicus Malabaricus, Hendrik van Rheede records that Indians learned the usage of nutmeg from the Indonesians through ancient trade routes, again the emphasis is perhaps on usage.

Nutmeg cultivation started at Kalady, in central Travancore (Kerala) around $18^{\text {th }}$ century. Reference is there about a Scotish man buying a parcel of land near Kalady and planting nutmeg, a species till then unknown to the local population. However, the Scotish owner left the country after few years and the 35 acre property came under the possession of a local Christian family. Some trees, believed to be planted by the Scotish man, more than 200 years ago, are still there. One Poonolil family is the current owner of the estate. Interestingly, the contribution of the Christian community, including the settlers, in popularising nutmeg in the state or even in the country is stellar and that saga needs to be documented properly (Sasikumar 2020). This Christian legacy of nutmeg in the state is also reflected in the names of the farmer's varieties of nutmeg like Kadukanmackel, Kallingal, Punnanthanam, Kochukudi, Kinattukara, Souwriyamakkal, Nirappel Kallivayal etc., which are all vernacular Christian family names.

In fact, the Christian legacy is writ large on the history of the spice. The original inhabitants of Moluccas, especially in the Central and South Moluccas too were mainly Christians (Noelle 2010) so also the colonists who spread the spice to different parts of the world and the interlocutors. Religion casting its influence in the transnational spread of few other cultivated crops is also known such as turmeric and
Hinduism (Sasikumar 2005), sugarcane and Islam (Galloway 1989; Cohen 2013) etc.

Kalady subsequently emerged as the main hub of nutmeg production and trade in Kerala. Nutmeg is produced in about 23478 ha in India (Spices Board, 2021) at present, Kerala leading the list. In addition to Kerala, the spice is grown in Maharashtra, Goa, Karnataka, Tamil Nadu, Andaman Islands etc.

\section{Conclusion}

Not many attempts are undertaken in the country to collect the species diversity of Myristica unlike the cultivar diversity (farmer's varieties). Myristica trobogarii is reported after a long gap of 124 years. Intensive surveys in the Western Ghats and North East India may yield few more endemic Myristica spp.

A taxonomic cleaning of the genus is also warranted to clearly discriminate the synonymous entities and evaluate the subspecies.

Many taxonomists are wary of the dioecious nature of the species and seasonal flowering besides the long juvenile phase of the trees. However, the vegetative propagation methods of the species can be exploited to circumvent these difficulties.

The relatively high frequency of the true seedling progeny derived farmer's varieties and the evolution of nutmeg towards monoecy are suggestive of the broad genetic base and phenotypic plasticity, respectively of the nutmeg population in India. The vegetative propagation method is a boon to fix any new variability.

Transnational spread of nutmeg is inseparably linked to colonialism. Though the different colonial powers strived for the nutmeg pie, the French colonial rulers were in the forefront. History reveals that nutmeg cultivation took root in the French colonial countries mainly due to the creolization of knowledge of the 
different stake holders, thus synthesizing the colonial botany or colonial horticulture which further advanced over the centuries.

Literature review reveals that during the last two decades more and more reports are emerging, at a global level, on the historical aspects of nutmeg. More historical investigations are warranted to bridge the gap in the history of nutmeg such as the pre and early CE history of the spice; the fate of the trees supposed to have introduced to Puducherry, India by the French Colonial rulers besides the chances of few of these seeds/saplings landing at Mahe, a French enclave in Kerala under Puducherry; the missing written account of the oldest nutmeg plantation of Kerala (Poonolil estate) including the early package of practices and circumventing the sexual dimorphism of the tree etc.

Thecontribution of variousKerala communities, especially the Christian settlers, in spreading nutmeg to different parts of Kerala and India besides its impact on the socio economic status of the people too warrants documentation.

\section{Acknowledgement}

The author expresses sincere gratitude to Sri. A Sudhakaran, Sr. Technical Officer and Dr. K V Saji, Principal Scientist (Econ. Bot.) ICAR-IISR for the photographs besides Mr.VA Muhammed Nissar, Scientist (SPM \& A), ICAR-IISR for some clarification on species identity and Dr. V P Swetha, for sparing some of the references collected during her Ph.D studies.

\section{References}

Aarthi S, Rema J, Sasikumar B, Saji K V \& Anandaraj M 2018 Diversity in floral characters of monoecious nutmeg (Myristica fragrans Houtt.) J. Spices Arom. Crops 27: 66-70.

Arunachalam K D \& Subhashini S 2011 Preliminary phytochemical investigation and wound healing activity of Myristica and Amanica leaves in Swiss albino mice. J. Med. Plants Res. 5: 1095-1106.
Aubery A 2012 No Innocent Spice: The Secret Story of Nutmeg, Life and Death. Allison Aubrey, National Public Radio, November 26, 2012.

Banik D, Bora P P, Sampath Kumar V \& Bezbaruah R L 2017 Conspectus on Indian Gymnacranthera and Myristica. Rheedea. 27: 1-12.

Bohra P, Waman AA \& Mishra S 2019 Crop Wild Relatives of Selected Perennial Horticultural Crops in Andaman and Nicobar Islands, India. In: Rajasekharan P E \& Ramanatha Rao V, Conservation and Utilization of Horticultural Genetic Resources (Eds.), Springer, pp 425-450.

Brixius D 2018 A hard nut to crack: nutmeg cultivation and the application of natural history between the Maluku islands and Isle de France (1750s-1780s). The Brit.J. Hist. Sci. 51: 585-606.

Brixius D 2015 A Pepper acquiring Nutmeg: Pierre Poivre, The French Spice Quest and the Role of Mediators in Southeast Asia, 1740s to 1770s. J. Western Soc. French History 43: 68-77.

Cohen R 2013 Sugar Love (A not so sweet story). National Geographic 224 (2): 78-85.

Drayton R 2000 Nature's government: science, imperial Britain, and the 'Improvement' of the world. Yale University Press, New Haven/London.

Galloway J H 1989 The Sugar Cane Industry: An Historical Geography from Its Origins to 1914. Cambridge University Press, 259 pp.

Govind M G, Dan M \& Rameshkumar K B 2020 Myristica trobogarii (Myristicaceae), a new species from southern Western Ghats, India. Phytotaxa 437: 206-212.

Haldankar P M, Nagwekar D D \& Khandekar P G 2004 Variability in nutmeg. Spice India 17: 9-12.

Hetharie H, Raharjo SHT, Rahado K \& Hehanussa ML 2015 Proc. $1^{\text {st }}$ Intern. Sem. Basic Sci., FMIPA Unpatti-Ambon June, 3rd-4th 2015. Faculty of Agriculture, Pattimura University, Jl. Ir. M. Putuhena, Poka, Ambon, Indonesia.

Hopkins D 1998 A colonial scientist, the end of the 
slave trade, and the colonization of West Africa. Ann. Meet. History Sci. Soc. Kansas City. IFEAT 2021 Socio economic status on nutmeg, 3 p.

Jaffrey A T 1860 On disease of the nutmeg trees in Singapore. Trans. \& Proc. Bot. Soc. Edinburgh 6: 368 .

Krishnamoorthy B, Rema J \& Mathew P A 2007 Tree spices. In: Peter K V \& Abraham Z (Eds.), Biodiversity in Horticultural Crops. Daya Publishing House, New Delhi, Pp. 256-277.

Lape P, Peterson E, Tanudirjo D, Shiung C C, Lee GAh, FieId J \& Coster A 2018 New Data from an Open Neolithic Site in Eastern Indonesia. The J. Arch. Asia and the Pacific 57: 222-243.

Lindorf H 2001 Un botánico francés en la Venezuela del siglo XVIII. Acta Bot. Venez. 24: 203-214.

Lindorf H 2002 La nuez moscada y la canela en América. Acta Bot. Venez. 25: 97-102.

Ly-Tio-Fane M 1958 Mauritius and the spice trade: The odyssey of Pierre Poivre. Mauritius Archives Publication Fund, No. 4. Esclapon, Port Louis.

Mabberley J D 2018 Mabberley's Plant Book: A portable dictionary of plants, their classification and uses. Fourth Edition. Cambridge University press, London, 610 pp.

Manjunatha B K, Mankani K L, Mukunda S K R, Divakara R, Sridar B K \& Paul B K 2011 Antioxidant and hepato protective effect of Myristica malabarica seed aril extracts on carbon tetrachloride induced hepatic damage. Global J. Biotech. Biochem. 6: 25-30.

Milton G 199 Nathaniel's nutmeg: How one man's courage changed the course of history. London:Hodder and Stoughton, 256pp.

Nanlohy, F N \& Semuel M Y 2020 Nutmeg (Myristica fragrans) of North Minahasa Molecular Entication Based on chloroplast DNA of matK gene. Indon. Biodiv. J. 1:60-68.

Noelle H 2010 Regulating the use of force in wars of national liberation: the need for a new regime: a study of the South Moluccas and Aceh, Martinus Nijhoff Publishers, 266pp.

Pakpahan A, Bermawie N \& Wiratno 2019
Indonesian's nutmeg for the world, synergizing consumers need while increasing farmer's welfare. 1st International Conference on Sustainable Plantation (1st ICSP 2019). IOP Conf. Series: Earth and Environmental Science 418 (2020) 012007. IOP Publishing.

Pickersgill B 2005 The Cultural History of Plants. Prance G \& Nesbitt, M (Eds.) Routledge, 166 pp.

Priyanka S C \& Mini Raj N 2016 Morphological characterization of unique genotypes of nutmeg. J. Tropical Agric. 54: 120-129.

Raj N M \& Nybe E V 2019 Search for mother trees culminates as high yielding varieties-a success story in nutmeg. Ind. J. Arecanut, Spices and Med. Plants 21: 3-10.

Ravindran PN 2017 The Encyclopedia of Herbs and Spices, Vol. 2, CABI.1176 pp.

Rema J \& Krishnamoorthy B 2014 Conservation of a nutmeg variant with yellow aril at Indian Institute of Spices Research. Indian J. Arec. Spices Med. Plants 17: 13-14.

Rema J, Saji K V, Sasikumar B \& Anandaraj M 2014 Monoecious nutmeg in Uttarkannada and Shimoga Districts of Karnataka. Indian J. Arec. Spices Med. Plants 16: 3-5.

Saji K V, Sasikumar B, Rema J, Sharon Aravind \& Nirmal Babu K 2019Spices Genetic Resources: Diversity, Distribution and Conservation. In: Conservation and Utilization of Horticultural Genetic Resources(Eds.) Rajasekharan P E \& Ramanatha Rao V, Springer, Pp.283-320.

Sasikumar B 2005 Genetic resources of Curcuma: diversity, characterization and utilization. Plant Genet. Res. 3: 230-251.

Sasikumar B 2020 A Borough for a spice-The unknown and known story. Kerala Calling, July 2020: 65-66.

Sasikumar B \& Aarthi, S 2016 Evolution of nutmeg towards monoecy. Spice India 20: 14 \& 16.

Sasikumar B, Saji K V \& Rema J 2017 A note on a seed sterile nutmeg from the secondary center of domestication. J. Spices Arom. Crops 26: 44-46.

Sasikumar B, Rema J \& Saji K V 2014 In the trail of elite nutmeg. Spice India 7: 8-14. 
Sheeja T E, Rosana O B, Swetha V P, Shalini R S, Siju S, Dhanya R, Rahul P R \& Krishnamoorthy B 2014 The 18S rDNA gene discriminates between red-listed and unexplored ethnomedicinal species of Myristicaceae restricted to humid tropics of India. Genet. Resour. Crop Ev. 61: 523-535.

Singh R H, Sankat C K \& Mujaffar S 2003 The nutmeg and spice industry in Grenada: Innovation and competitiveness - A Case Study Workshop on the Role of Science, Technology and Innovation in Increasing Competitiveness in the Productive. The University of the West Indies, St. Augustine, Trinidad, November 2003.

Sonnerat M 1776 Voyage à la Nouvelle Guinée, dans lequel on trouve la description des lieux, des observations physiques \& morales, \& des détails relatifs à l'histoire naturelle dans le regne animal \& le regne végétal. Ruault, Paris.

Spices Board, Govt. of India 2021 Major Spices State wise Area \& Production. 4 p.

Sreedharan G \& Indulkar M 2018 New distributional record of the northern most Myristica swamp from the Western Ghats of Maharashtra. Curr.Sci. 115: 1434-1435.

Swetha V P, Sheeja T E \& Sasikumar B 2019 DNA barcoding to resolve phylogenetic relationship in Myristica spp. J. Spices Arom. Crops 28: 131-140.

Topsfield J \& Rompies K 2017 The forgotten
Indonesian island that was swapped for Manhattan. The Sunday Morning Herald July 21, 2017.

Wahyuni S \& Bermawie N 2020 Yield and fruit morphology of selected high productive Papua nutmeg trees (Myristica argentea Warb.) 1st International Conference on Sustainable Plantation (1st ICSP 2019). IOP Conf. Series: Earth and Environmental Science 418: 012032. IOP Publishing.

Vikram H C, Mini Raj N, Prasannakumari K T, Mathew D \& Nybe E V 2016 Variability in fruit characteristics of nutmeg under Kerala condition. J. Spices Arom. Crops 25: 187-194.

Warburg O 1897 a Die Muskatnuss: ihre Geschichte, Botanik, Kultur, Handel und Verwertung sowie ihre Verfälschungen und Surrogate. Wilhelm Engelmann, Leipzig.

Warburg O 1897 b Monographie der Myristicaceen. Nova Acta: Abhandlungen der Kaiserl. Leopold. Carol. Deutschen Akademie der Naturforscher, Vol. 68. Wilhelm Engelmann, Halle.

Wellington DC 2006 French East India Companies: An Historical Account and Record of Trade. Hamilton Books, 254 pp.

Weiss E A 2002 Spice Crops, CABI, 411pp.

Zumbroich T J 2005 The Introduction of Nutmeg (Myristica fragrans Houtt.) and Cinnamon (Cinnamomum verum Presl.) to America. Acta. Bot. Venez. 28: 155-16. 